\title{
APPLICATION OF TERRITORIAL PRINCIPLES AGAINST PEDOPHILE CRIMINAL ACT PERPETRATORS PERPETRATED BY FOREIGN CITIZENS
}

\author{
Wiranda Putri Madamba, Fenty U. Puluhulawa, Lisnawaty W. Badu, \\ Jufryanto Puluhulawa, Mohamad Rivaldi Moha \\ Law Faculty of Gorontalo State University Jendral Sudirman Street, Gorontalo City, 96128. \\ wirandaputrimadamba@gmail.com, fentypuluhulawa@ung.ac.id, lisnawaty69@ung.ac.id, \\ jufryantopuluhulawa@ung.ac.id,Mohamadrivaldi@ung.ac.id
}

\begin{abstract}
Indonesian criminal law adheres to various principles that form the basis for solving problems, especially in problems related to two or more countries. One of the principles recognized and in line with the research, in this case, is the territorial principle, which is a useful principle in determining the limits of validity of criminal law provisions based on place or location. This study aims to analyze the application of the territorial principle to perpetrators of pedophilia crimes committed by foreign nationals. The method used in this study is a normative type of research that uses the law approach and case studies. The results of this study indicate that should be based on the principle of criminal law, namely the territorial principle, Indonesian law will be applied to anyone who commits a crime in Indonesia, including in this case foreign citizens who commit pedophilia crimes, especially a sovereign state has exclusive jurisdiction in the environment. the territory itself is called territorial sovereignty so that the state has full jurisdiction to punish people who commit crimes against the law in the territory of the country. In reality, this territorial principle cannot be applied to this case because the suspect is still in the process of waiting for the results of approval or rejection of extradition by the Ministry of Law and Human Rights of the Republic of Indonesia, considering that the suspect is a foreign citizen and is also a fugitive in his home country, namely the United States of America. so that the country of origin sends a letter of request for extradition and this extradition request is still in the process of being followed up.
\end{abstract}

Keywords : Territorial Principles; Pedophilia Crimes; Foreign Nationals. 


\section{Introduction}

Law is a very important thing in the world in regulating the procedures for social life and the life of the nation and state. It is undeniable that without the law, social life would not be possible to be organized in such a way, as Hans Kelsen said "that law is a system of norms that regulate all human behavior." 1 This was also emphasized by Andre Ata Ujan that "the most basic role of law is to guarantee justice and truth in the social order." 2

Indonesia which is a country of law ${ }^{3}$ There are various types of laws that are the same, consisting of all rules which, if violated, will be subject to sanctions and can be enforced by the competent authorities in Indonesia. "Many people then violations and crimes are threatened with punishment in the form of suffering or torture for those who violate them." 4 In principle, the concept of the rule of law is idealized that what must be made commander in the dynamics of state life is law, not politics or economics. ${ }^{5}$

In criminal law, there are several national criminal principles which of course are the basis for the formation and application of law which of course has been recognized by international law to be the basis of a country in applying the law applicable in that country. crimes that occur

1 Donald Albert Rumokoy Dan Frans Maramis. (2016). Pengantar Ilmu Hukum. Jakarta: PT. Rajagrafindo. HIm 12

${ }^{2}$ Ujan, A. A. (2008). Filsafat Hukum: Membangun Hukum, Membela Keadilan. Jogjakarta: Kanisius

${ }^{3}$ Undang-Undang Dasar Negara Republik Indonesia 1945 Pasal 1 Ayat (3)

${ }^{4}$ Masriani, Y. T. (2015). Pengantar Hukum Indonesia. Jakarta: Sinar Grafika.HIm 60

5 Asshiddiqie, J. (2017). Gagasan Negara Hukum Indonesia. Retrieved 2021 from Pengadilan Negeri Gunungsitoli: between two or more countries, namely "the principle of legality, the principle of territoriality, the principle of passive and active nationality, the universal principle, and the non-retroactive principle, and the principle of neb is in idem". The existence of these principles is very useful for resolving cross-territorial issues in connection with the jurisdictional links of the countries concerned."6

Recently, the Metro Jaya Regional Police named an American citizen with the initials RAM as a suspect in a case of sexual intercourse with a minor with a maximum penalty of 15 years in prison in Law Number 35 of 2014 concerning Child Protection. being wanted by the Federal Bureau of Investigation (FBI) based on information received from the FBI, RAM is suspected of having committed fraud with the bitcoin stock investment mode. RAM managed to defraud up to 22 million US dollars or around Rp. 10.8 trillion. Ram is also a recidivist or repeats criminal in cases of underage sexual harassment in America. ${ }^{7}$

Seeing that the scene of the case is an Indonesian state that adheres to the territorial principle, the case should have been decided by using national law but in reality, the American citizen is a fugitive in his country of origin and as stated by the head of

gunungsitoli.go.id/artikel/gagasan-negara-hukumindonesia

6 Prasetyo, K. (2015). Penerapan Kaidah-Kaidah Hukum Internasional Dalam Masyarakat Internasional. Justice Pro : Jurnal Ilmu Hukum, 2(2).

7 Bomantama, R. (2020). Polisi: Rumah Pedofil Buronan FBI Setiap Hari Didatangi Perempuan di Bawah Umur. Retrieved 2021, from inews.id: https://www.inews.id/news/megapolitan/polisi-rumahpedofil-buronan-fbi-setiap-hari-didatangi-perempuandi-bawah-umur 
public relations at the Metro Jaya Police that the Federal Bureau of Investigation has sent a letter requesting the extradition of the suspect ram in the case of sexual abuse committed against minors, to the ministry of law and human rights (Kemenkumham). The extradition request was submitted by the FBI through the United States Embassy.

"The extradition request letter has been sent by the FBI through the embassy to the Ministry of Law and Human Rights (Kemenkumham) because Indonesia does not have an extradition agreement with the United States because of that, the mechanism for the process must go through the Ministry of Law and Human Rights. The Head of Public Relations of Polda Metro Jaya said that currently, his party is still waiting for the extradition process that the FBI has submitted to the Ministry of Law and Human Rights." 8

Looking at the brief description of the case above, the researcher feels that this case is very interesting to discuss considering the place where the crime took place in the State of Indonesia, where the State of Indonesia adheres to the territorial principle, then the suspect of a pedophile crime who is a fugitive from the FBI and his country of origin has sent a letter of extradition request but There is no extradition treaty between Indonesia and America.

\section{Problem Statement}

Based on the background that has been written, the researcher formulates a problem

8 Kompas.Com Dengan Judul "Jejak Kasus Russ Medlin Di AS, Terjerat Kejahatan Seksual Dan Penipuan Bitcoin Hingga Raup 722 Juta Dollar AS", Https://Megapolitan.Kompas.Com/Read/2020/06/16/2 1472311/Jejak-Kasus-Russ-Medlin-Di-As-TerjeratKejahatan-Seksual-Dan-Penipuan?Page=All. formulation about how to apply the territorial principle to perpetrators of pedophilia crimes committed by foreign nationals?

\section{Research methods}

1. Type of Research

This research is a type of normative legal research.

2. Approach Method ${ }^{9}$

In seeking scientific truth, this research uses several approaches in legal science, as follows:

a. Statute approach

b. case approach.

\section{Result and Discussions}

Application of Territorial Principles Against Pedophile Criminal Act Perpetrators Perpetrated by Foreign Citizens

The territorial principle is "a useful principle in determining the limits of the validity of criminal law provisions based on place or location," 10 This principle indirectly shows that the country where the crime occurred has the authority in its territory, meaning that the country can enforce the law on anyone who is in the territory of the country because of that, in determining territorial boundaries, of course, it must be used as the most basic basis through legal principles that form the basis for the enactment of concrete legal regulations. In line with this, van Hattum said that,

9 Amiruddin dan Zainal Asikin. (2012). Metode Penelitian Hukum. Jakarta: Rajawali Pers

10 Walintukan, S. (2018). Batas-Batas Berlakunya Ketentuan Pidana Dalam Peraturan PerundangUndangan Menurut Tempat (Pasal 2 Sampai Pasal 8 KUHP) Dari Aspek Perlindungan Terhdap Warga Negara Indonesia Di Luar Negeri. Lex Crimen, 7(7), 71. 
"Each country is obliged to guarantee security and order within the territory of their respective countries. Therefore, judges from each country can try people who within the territory of their respective countries have committed a crime, by enacting the Criminal Law in their country. This means that the criminal law of a country can not only be applied to its citizens but also to foreigners who within the territory of their country are known to have committed a crime." 11

Indonesia itself has regulated this territorial principle in Article 2 of the Criminal Code (KUHP) where the criminal provisions in Indonesian legislation apply to everyone who commits a crime in the territory of Indonesia. 12

If we look at the Criminal Code, we will see that it is clearly stated in Articles 2-8 of the Criminal Code regarding the sharing of principles adopted by the Indonesian state which have relevance to international law, such as:

\section{Territorial Principle}

In article 2 of the Criminal Code where criminal provisions in Indonesian legislation apply to all people who commit criminal acts in Indonesia. ${ }^{13}$

The territorial principle is useful in determining the place of enactment of a crime, indirectly this principle shows that the country where a crime occurs has authority within its territory, meaning that the country can enforce the law on anyone who is in the territory of the country because of that, in determining territorial boundaries, of

11 Litigasi. (2018). Teritorial Berlakunya Hukum Pidana Indonesia. Retrieved 2021, from Litigasi.co.id: https://litigasi.co.id/hukum-pidana/113/teritorialberlakunya-hukum-pidana-indonesia

12 Handoko Duwi (2017). Asas Asas Hukum Pidana Dan Hukum Panitensier Indonesia. Pekanbaru : Hawa dan Ahwa Press. course, must be used as the most basic basis through the legal principle which is the basis for the enactment of concrete legal regulations. ${ }^{14}$

2. Passive National Principle

The Passive National Principle is also known as the principle of protection, which means that all criminal laws in Indonesia apply to all people, both Indonesian citizens and foreign nationals who commit crimes outside the territory of Indonesia, in which the national interest of the Indonesian State is violated in the criminal act. therein, as regulated in Article 4 of the Criminal Code, what is meant by Indonesia's interests are: 15

a. State security and ensuring the safety and dignity of the head of state and his representatives;

b. guaranteed currency as well as stamp duty and brands that have been and are only issued by the Indonesian government;

c. Ensuring that Indonesian employees do not commit criminal acts while outside the territory of Indonesia;

d. Guaranteed documents or debt certificates issued by the Indonesian government;

e. Guaranteed security, the captain and passengers of Indonesian boats do not commit criminal acts on voyages outside the territory of Indonesia.

In principle, "the legal basis of this passive national principle is that every sovereign state has the right to protect its legal interests even if those legal

\footnotetext{
${ }^{13}$ Pasal 2 KUHP

14 Tomalili Rahmanuddin. (2019). Hukum Pidana, Yogyakarta : Deepublish. HIm.109

15 Ibid. HIm 72
} 
interests are violated abroad and not by its citizens." 16

3. Principle of Personality or active nationality

This principle is a principle that regulates all criminal acts committed by Indonesian citizens outside the territorial limits of the Indonesian State, this is based on Article 5 of the Criminal Code.

To clarify the discussion of the principle of personality as written in Article 5 of the Criminal Code, "it says that the provisions of Indonesian criminal law apply to Indonesian citizens who commit crimes outside the territory of the Indonesian state. This principle is called active nationality because it relates to the criminal activity of a citizen." 17 According to R. Soesilo, "this article lays down the principle of nationaliteit aktief or personaliteit." 18

The principles mentioned above can be excluded by an extradition treaty which is an exception recognized by international law under Article 9 of the Criminal Code. ${ }^{19}$

In international law, every country is considered to have the authority to carry out legal provisions against every crime that occurs in the territory of that country. As for enactment of law against citizens who are outside the territory of the country as an obligation as well as responsibilities as citizens. ${ }^{20}$

16 Octora, R. (2018). Penerapan Asas Nasionalitas Pasif dan Pemidanaan Pembantu Tindak Pidana Perdagangan Oraang Dalam RKUHP. Kertha Patrika, 40(3), 166.

17 Hasanah, S. (2018). Arti Asas Personalitas atau Asas Nasionalitas Aktif dalam Hukum Pidana. Retrieved 2021, from Hukumonline.com: https://m.hukumonline.com/klinik/detail/ulasan/lt5b07 770d798f2/arti-asas-personalitas-atau-asasnasionalitas-aktif-dalam-hukum-pidana/
In the scope of the discussion of this case, the suspect of this criminal act of pedophilia is a fugitive from his country of origin and his country of origin has sent a letter of request for extradition in Indonesia through diplomatic channels but until now there has been no decision to accept or reject the extradition request, while Article 27 of Law No. 1 of 1979 clearly states that no later than 7 days after receiving the official report regarding the extradition request, the prosecutor will then provide a written reason by asking the district court where the suspect is being held, of course, to then examine and determine whether or not the suspect can be extradited.

It should be based on the principle of criminal law, namely the territorial principle, Indonesian law will be enforced by anyone who commits a crime in Indonesia, including in this case foreign nationals who commit pedophilia crimes, especially "a sovereign state has exclusive jurisdiction over its territory which is called territorial sovereignty so that the state has full jurisdiction to implement the provisions of national law to anyone who violates the law in the country's territory," 21 but because the United States is still waiting for the request for extradition by the United States to Indonesia to be approved by the Ministry of Law and Human Rights of the Republic of Indonesia, this case is delayed in terms of

\footnotetext{
18 Soesilo, R. (1991). Kitab Undang-Undang Hukum Pidana (KUHP) Serta Komentar-Komentarnya Lengkap Pasal Demi Pasal. Bogor: Politeia.

19 Pasal 9 KUHP

20 Mustaqimah, L. (2016). Penerapan Asas Nasionalitas Pasif Terhadap Tindak Pidana Teknologi Informasi. Badamai Law Journal, 1(2).

${ }^{21}$ Santosa, M. I. (2018). Kedaulatan Dan Yuridiksi Negara Dalam Sudut Pandang Keimigrasian. Binamulia Hukum, 7(1), 3.
} 
imposing criminal threats related to the crime of pedophilia, this certainly has an impact on law enforcement in Indonesia.

Conceptually, according to Article 1 of Law Number 1 of 1979 concerning Extradition, what is meant by extradition is

"Delivery by a country to a country requesting the surrender of a person who is suspected or convicted of committing a crime outside the territory of the submitting country and within the jurisdiction of the territory of the country requesting the surrender, because it is authorized to try and convict him."

Based on international custom, extradition is based on an agreement between countries as regulated in Article 2 Paragraph (1) of Law Number 1 of 1979 concerning Extradition but considering that in its development until now there is no extradition treaty between Indonesia and the United States of America, then there is no extradition treaty between Indonesia and the United States of America. Referring to Article 2 paragraph (2) of Law Number 1 of 1979 concerning Extradition, extradition can be carried out based on good relations between countries and if the interests of the Republic of Indonesia so desire. This is what makes Indonesia not immediately able to actualize the territorial principle in the process of criminalizing criminal cases committed by foreign nationals of the United States of America especially in the decision-making process involving several agencies, namely the Ministry of Law and Human Rights, the Indonesian National Police, the Attorney General's Office. and also the Ministry of Foreign Affairs of the Republic of Indonesia so that of course coordination and in-depth study of the extradition request is required as mandated in Article 24 of Law Number 1 of 1979 concerning Extradition.

\section{Conclusion}

The application of the territorial principle against perpetrators of pedophilia crimes committed by foreign nationals does not necessarily apply to this case because the suspect is still in the process of waiting for the results of approval or rejection of extradition by the Ministry of Law and Human Rights of the Republic of Indonesia, considering that the suspect is a citizen of the Republic of Indonesia. foreigner and also a fugitive in his country of origin, namely the United States of America, so that his country of origin has sent a letter of request for extradition and this request for extradition is still in the process of being followed up.

\section{Suggestion}

1. To the government, especially the legal apparatus in the field of the Ministry of Law and Human Rights of the Republic of Indonesia so that they can accelerate the process of approval or rejection of the extradition so that the law can be enforced as soon as possible considering that it is very clearly written in article 27 of the extradition law that no later than 7 days after the Prosecutor's Office receives the official report regarding the extradition, then the reason must be clearly stated in writing so that the district court, in particular, should immediately examine and immediately give a decision whether or not the suspect can be extradited.

2. To the FBI as the main investigative agency of the United States Department of Justice (DOJ) so that it would be faster to notify Interpol if there are fugitives 
who leave their countries so that red notices can be seen before criminal fugitives enter other countries.

3. To the immigration authorities, especially the Directorate General of Immigration, so that they can carry out a monitoring system in the field of immigration, of course, for foreign citizens starting from foreign citizens, they are still in the process of making visas so that they can enter the country of Indonesia and then when they have entered the country of Indonesia. must be checked through the immigration authorities.

4. Then to law enforcement officers in Indonesia, if they decide to accept the extradition of a foreign citizen with the initials RAM, it is hoped that this pedophilia sanction in Indonesia can be continued in the requesting country considering that RAM was asked for extradition, not because of a pedophilia case but a case of pedophilia. what he did in his home country before he fled to Indonesia.

5. To the Indonesian government so that in the future it can anticipate cases like this, researchers also hope that Indonesia can ratify the extradition treaty with America.

\section{REFERENSI}

\section{Buku}

Amiruddin dan Zainal Asikin. (2012). Metode Penelitian Hukum. Jakarta: Rajawali Pers. Donald Albert Rumokoy Dan Frans Maramis. (2016). Pengantar Ilmu Hukum. Jakarta: PT. Rajagrafindo.
Handoko Duwi (2017). Asas Asas Hukum Pidana Dan Hukum Panitensier Indonesia. Pekanbaru : Hawa dan Ahwa Press.

Masriani, Y. T. (2015). Pengantar Hukum Indonesia. Jakarta: Sinar Grafika.

Ujan, A. A. (2008). Filsafat Hukum: Membangun Hukum, Membela Keadilan. Jogjakarta: Kanisius

Soesilo, R. (1991). Kitab Undang-Undang Hukum Pidana (KUHP) Serta KomentarKomentarnya Lengkap Pasal Demi Pasal. Bogor: Politeia.

Tomalili Rahmanuddin. (2019). Hukum Pidana, Yogyakarta : Deepublish.

\section{Jurnal}

Mustaqimah, L. (2016). Penerapan Asas Nasionalitas Pasif Terhadap Tindak Pidana Teknologi Informasi. Badamai Law Journal, 1(2).

Octora, R. (2018). Penerapan Asas Nasionalitas Pasif dan Pemidanaan Pembantu Tindak Pidana Perdagangan Oraang Dalam RKUHP. Kertha Patrika, 40(3)

Prasetyo, K. (2015). Penerapan KaidahKaidah Hukum Internasional Dalam Masyarakat Internasional. Justice Pro : Jurnal Ilmu Hukum, 2(2).

Santosa, M. I. (2018). Kedaulatan Dan Yuridiksi Negara Dalam Sudut Pandang Keimigrasian. Binamulia Hukum, 7(1).

Walintukan, S. (2018). Batas-Batas Berlakunya Ketentuan Pidana Dalam Peraturan Perundang-Undangan Menurut Tempat (Pasal 2 Sampai Pasal 8 KUHP) Dari Aspek Perlindungan Terhdap Warga Negara 
Indonesia Di Luar Negeri. Lex Crimen, 7(7).

\section{Peraturan Perundang-Undangan}

Undang-Undang Dasar Negara Republik Indonesia 1945.

Kitab Undang-Undang Hukum Pidana

\section{Website}

Asshiddiqie, J. (2017). Gagasan Negara Hukum Indonesia. Retrieved 2021 from Pengadilan Negeri Gunungsitoli: https://www.pngunungsitoli.go.id/artikel/gagasannegara-hukum-indonesia

Bomantama, R. (2020). Polisi: Rumah Pedofil Buronan FBI Setiap Hari Didatangi Perempuan di Bawah Umur. Retrieved 2021, from inews.id: https://www.inews.id/news/megapo litan/polisi-rumah-pedofil-buronanfbi-setiap-hari-didatangi-perempuandi-bawah-umur

Hasanah, S. (2018). Arti Asas Personalitas atau Asas Nasionalitas Aktif dalam Hukum Pidana. Retrieved 2021, from Hukumonline.com:

https://m.hukumonline.com/klinik/d etail/ulasan/lt5b07770d798f2/artiasas-personalitas-atau-asasnasionalitas-aktif-dalam-hukumpidana/

Kompas.Com Dengan Judul "Jejak Kasus Russ Medlin Di AS, Terjerat Kejahatan Seksual Dan Penipuan Bitcoin Hingga Raup 722 Juta Dollar AS", Https://Megapolitan.Kompas.Com/R ead/2020/06/16/21472311/JejakKasus-Russ-Medlin-Di-As-TerjeratKejahatan-Seksual-DanPenipuan?Page=All.

Litigasi. (2018). Teritorial Berlakunya Hukum Pidana Indonesia. Retrieved 2021, from Litigasi.co.id: pidana/113/teritorial-berlakunyahukum-pidana-indonesia 